\title{
MENINGKATKAN MINAT BELAJAR SISWA MELALUI KONSELING EKLEKTIK DENGAN MENGGUNAKAN MEDIA SUPERHERO PADA SISWA KELAS VIII-6 SMP NEGERI 5 SIBOLGA
}

\author{
Elistiani Tambunan \\ Guru SMP Negeri 5 Sibolga
}

\begin{abstract}
Abstrak
Penelitian ini bertujuan untuk mengetahui minat belajar siswa kelas VIII SMP Negeri 5 Sibolga sebelum dan sesudah dilakukan konseling eklektik dengan menggunakan media superhero. Penelitian ini merupakan penelitian tindakan kelas yang terdiri dari dua siklus. Populasi penelitian adalah seluruh siswa kelas VIII SMP Negeri 5 Sibolga tahun ajaran 2015/2016. Pemilihan sampel dilakukan dengan teknik cluster random class. Sampel yang diambil adalah satu kelas dan dilakukan konseling eklektik dengan menggunakan media superhero. Instrumen yang digunakan adalah tes minat belajar dalam bentuk angket. Dari hasil analisis data diperoleh hasil rata-rata pretes sebesar 62,75 setelah dilakukan tindakan diperoleh hasil siklus I sebesar 75,75 kemudian pada siklus II mengalami peningkatan menjadi 90,75. Hasil penelitian menunjukkan adanya peningkatan minat belajar siswa melalui konseling eklektik dengan menggunakan media superhero di kelas VIII SMP Negeri 5 Sibolga.

Kata Kunci : Konseling Eklektik, Minat Belajar, Media Superhero

PENDAHULUAN

Menciptakan Kegiatan Belajar

Mengajar (KBM) yang menarik merupakan tuntutan bagi seorang guru. Hal tersebut seperti yang diungkapkan oleh Djamarah dan Zain (2010), kegiatan belajar mengajar merupakan suatu suasana yang menggairahkan dan menyenangkan yang secara sengaja diciptakan oleh guru untuk membelajarkan siswanya. Suasana kegiatan belajar mengajar dikatakan berarti bagi siswa apabila dapat menumbuhkan minat belajar siswa.

Minat belajar diperlukan dalam pembelajaran dikarenakan minat merupakan penyebab kegiatan dan partisipasi dalam kegiatan (Abror, 1993). Selain itu, menurut Hilgrad (Slameto, 2010) siswa yang memiliki minat dalam belajar akan ditandai dengan kecenderungan yang tetap untuk

memperhatikan dan mengenang beberapa kegiatan. Melalui minat belajar pula akan berimbas pada prestasi siswa. Siswa yang memiliki minat belajar yang besar akan cenderung menghasilkan prestasi yang tinggi, sebaliknya minat belajar yang kurang akan menghasilkan prestasi yang rendah (Dalyono, 2009).

Minat pada dasarnya adalah penerimaan diri akan suatu hubungan antara diri sendiri dengan sesuatu diluar diri. Semakin kuat atau dekat hubungan tersebut, semakin besar minat siswa untuk belajar. "Berdasarkan pendapat Slameto mengenai pengertian belajar dan minat, maka dapat ditarik kesimpulan bahwa minat belajar adalah suatu rasa tertarik siswa terhadap suatu hal untuk memperoleh ilmu yang baru dan berguna untuk dirinya tanpa ada yang memaksa.
\end{abstract}


Salah satu faktor yang menyebabkan timbulnya kesulitan dalam belajar adalah karena minat siswa tidak ada terhadap pelajaran tersebut. Kegiatan belajar dapat berhasil dengan baik apabila ada pemusatan perhatian terhadap pelajaran dan salah satu faktor yang menyebabkan terpusatnya perhatian dalam minat.

Minat siswa dapat diapresiasikan melalui suatu pernyataan, misalnya siswa lebih menyukai pelajaran matematika daripada pelajaran yang lainnya. Siswa yang memiliki minat terhadap subjek tertentu cenderung untuk memberikan perhatian yang lebih besar terhadap subjek tersebut. Mengembangkan minat terhadap pelajaran pada dasarnya adalah membantu siswa melihat bagaimana hubungan antara materi yang diharapkan untuk dipelajarinya dengan dirinya sendiri sebagai individu. Bila siswa menyadari bahwa belajar meupakan suatu alat untuk mencapai beberapa tujuan yang dianggapnya penting dan bila siswa melihat bahwa hasil dari pengalaman belajarnya akan membawa kemajuan pada dirinya kemungkinan siswa akan berminat untuk mempelajarinya.

Berdasarkan pengalaman peneliti sebagai salah satu guru BK di SMP Negeri 5 Sibolga sering dijumpai siswa yang tidak bersemangat dalam mengikuti pelajaran, terkadang ada yang tidak peduli dengan penjelasan guru, jika diberi pertanyaan siswa tersebut tidak bisa menjawab, siswa tidak tertarik untuk mengikuti pelajaran yang guru sajikan. Upaya yang dilakukan guru untuk mengatasi hal tersebut adalah dengan memberikan arahan (nasehat), namun cara ini sangat tidak efektif dalam menangani siswa tersebut.

Sebagai guru BK maka peneliti penting untuk memberikan tindakan lebih lanjut guna meningkatkan minat belajar siswa dengan menggunakan pendekatan konseling individual.

Tolbert (2009) menyatakan bahwa konseling adalah hubungan pribadi yang dilakukan secara tatap muka antara dua orang dalam mana konselor melalui hubungan itu dengan kemampuan-kemampuan khusus yang dimilikinya, menyediakan situasi belajar. Dalam hal ini konseling dibantu untuk memahami diri sendiri, keadaannya sekarang, dan kemungkinan keadaannya masa depan yang dapat ia ciptakan dengan menggunakan potensi yang dimilikinya, menyediakan situasi belajar. Dalam hal ini konseli dibantu untuk memahami diri sendiri, keadaannya sekarang dan kemungkinan keadaannya masa depan yang dapat ia 
diciptakan dengan menggunakan potensi yang dimilikinya, demi untuk kesejahteraan pribadi maupun masyarakat. Lebih lanjut konseli dapat belajar bagaimana memecahkan masalah-masalah dan menemukan kebutuhan-kebutuhan yang akan datang. Untuk itu peneliti akan melakukan pendekatan konseling eklektik dengan media superhero.

\section{Latipun (2011) mengemukakan} pendekatan konseling eklektik adalah suatu pendekatan yang berusaha menyelidiki berbagai sistem metode dan teori dengan tujuan untuk memahami dan menerapkannya dalam situasi konseling. Pendekatan eklektik juga dikenal sebagai konseling integratif. Hal ini tentu saja disebabkan karena orientasi pendekatan eklektik adalah penggabungan teori-teori konseling dengan mempetimbangkan kelebihan dan kekurangan pada masing-masing teori tersebut. Karena dalam praktiknya pendekatan elektrik menggunakan semua teori konseling maka pendekatan ini tidak pernah menggunakan konsep-konsep teori secara tetap tetapi akan memilih konsep teori apakah yang paling sesuai dengan masalah konseli. Oleh karena itu, pendekatan eklektik bersifat fleksibel dalam penggunaannya. Selain itu, pendekatan eklektik juga besifat ilmiah, sistematik dan logis.

Selanjutnya Corey (dalam Namora 2011) juga menganjurkan agar konselor menggunakan pendekatan eklektik sebagai kerangka kerjanya dalam menangani konseli. Hal ini berdasarkan anggapan bahwa juga konselor hanya terpaku pada satu teori yang dianggapnya paling penting, maka secara tidak langsung ia telah mengesampingkan teori lain yang mungkin saja lebih efektif dan bermanfaat bagi konseli. Selain itu, dimensidimensi lain yang bernilai dari tingkah laku manusia akan terlewati jika konselor hanya membatasi pada satu teori konseling saja.

$$
\text { Rubin C. Lawrence }
$$
mengemukakan : "Konseling dapat dilakukan dengan menggunakan media superhero. Superhero mempunyai kekuatan dan mentransformasikan keyakinan dan kekuatan tersebut. Demikian juga konseli memahami kekuatan mereka untuk menghadapi kekerasan atau terisolasi yang mereka tidak dapat atasi. Superhero dapat menyelidiki dan mengubah situasi yang dihadapinya. Dengan demikian konseli juga dapat situasi untuk mengembangkan daya juang dan penafsiran dalam menghadapi persoalan. Kemampuan untuk beradaptasi terhadap pengalaman mentransformasikan diri ini didasarkan pada 
perjuangan untuk menghadapi persoalan. Meskipun konseli tidak memiliki kekuatan seperti superhero, tetapi kekuatan fisik dan kekuatan moral superhero dapat ditransformasikan untuk mengubah dan membantu konseli mengatasi ketidakmampuan dan kekurangan yang dirasakan.

Beranjak dari fenomena belum semua siswa di sekolah dapat meningkatkan minat belajarnya, padahal ini sangat diperlukan dalam memusatkan perhatiannya terhadap pelajaran. Sementara cara yang dilakukan guru konselor belum efektif untuk meningkatkan minat belajarnya, maka perlu menguji apakah konseling eklektik dengan media superhero dapat meningkatkan minat belajar siswa.

\section{KAJIAN PUSTAKA \\ Belajar}

Slameto (2010) mengungkapkan bahwa belajar adalah suatu proses usaha yang dilakukan seseorang untuk memperoleh suatu perubahan tingkah laku yang baru secara keseluruhan, sebagai hasil pengalamannya sendiri dalam interaksi dengan lingkungannya. Perubahan tingkah laku tersebut menyangkut perubahan yang bersifat pengetahuan (kognitif) dan keterampilan (psikomotor) maupun menyangkut nilai dan sikap (afektif).
Menurut Winkel (2009) bahwa belajar adalah aktivitas mental/psikis yang berlangsung dalam interaksi aktif dengan lingkungan yang menghasilkan perubahanperubahan dalam pengetahuan-pemahaman, keterampilan dan nilai-sikap. Jadi hasil belajar berbentuk perubahan perilaku yang terjadi setelah orang (individu) melakukan aktivitas belajar tertentu. Perubahan itu baik dalam kemampuan kognitif, psikomotor, maupun afektif yang akan nampak pada saat orang melakukan sesuatu.

\section{Minat Belajar}

Menurut Elizabeth B. Hurlock (1978), minat adalah sumber motivasi yang mendorong orang untuk melakukan apa yang mereka inginkan bila mereka bebas memilih. Sama halnya dengan yang diungkapkan oleh Slameto (2010), minat merupakan rasa lebih suka dan rasa keterikatan pada suatu hal atau aktivitas, tanpa ada yang menyuruh. Dengan sendirinya minat timbul tanpa ada siapa yang menyuruhnya.

Kecenderungan dan kegairahan yang tinggi atau keinginan yang besar terhadap sesuatu dinamakan dengan minat (Muhibbin Syah, 2010).

Slameto (2010) mengutarakan bahwa siswa yang berminat mempunyai ciri-ciri sebagai berikut: 
1. Ada rasa suka dan senang pada suatu hal tanpa ada yang menyuruh.

2. Diekspresikan melalui suatu pernyataan.

3. Lebih menyukai suatu hal daripada hal lainnya.

4. Dimanifestasikan melalui partisipasi dalam suatu aktivitas.

5. Cenderung untuk memberikan perhatian lebih besar terhadap subjek tersebut.

\section{Konseling Eklektik}

Konseling eklektik dapat disebut dengan pendekatan konseling integratif, yang menunjukkan dalam konseling ini berpegang pada pandangan teoritis dan pendekatan, yang merupakan perpaduan dari berbagai unsur yang diambil atau dipilih dari berbagai konsepsi serta pendekatan.Tujuan dari layanan ini adalah menggantikan tingkah laku yang terlalu kompulsif dan emosional dengan tingkah laku yang bercorak lebih rasional dan lebih konstruktif.

Promotor utama dari konseling eklektik adalah Frederick Thorne yang mulai mengelola majalah Journal of Clinical Psychology pada tahun 1945 dan menyebarkan luaskan rangkaian pandangannya dalam beberapa buku, antara lain Principles of Personality Counseling.

Dryden \& Norcross dalam Gunarsa (1992) mengemukakan bahwa konseling eklektik adalah memilih apa yang baik dari berbagai macam sumber, gaya dan sistem untuk menghadapi masalah-masalah khusus.

Menurut Gilliland dalam Arintoko (2011) mengemukakan bahwa konseling eklektik adalah teori konseling yang tidak memiliki teori atau prinsip khusus tentang kepribadian. Sedangkan pandangan Shertzer \& Stone dalam buku Fundamentals of Counseling, konseling eklektik sebagaimana dikonsepsikan oleh Thorne mengandung unsur positif dan negatif.

Cooper (Surya, 2003) menyarankan bahwa tiga bentuk dasar pengalaman (afektif, kognitif dan behavioral) menggambarkan unsur-unsur internal sistem lingkungan klien. Kemudian hal itu dipengaruhi oleh lingkungan eksternal siswa yang terdiri atas faktor keluarga, sosial yang berada diluar diri pribadi siswa. Konselor yang menggunakan model eklektik akan memandang masalah siswa dalam kaitan dengan unsur-unsur eksternal dan internal.

Dari uraian diatas dapat dikemukakan bahwa konseling eklektik adalah konseling yang memilih teori yang baik dari bermacammacam teori, metode dan pengalamanpengalaman praktik untuk dipergunakan bersama-sama dalam menghadapi konseli. 


\section{Media Pembelajaran}

Secara harfiah, media berarti perantara atau pengantar. Sadiman (dalam Kustandi, 2011) mengemukakan bahwa media adalah perantara atau pengantar pesan dari pengirim ke penerima pesan. Selanjutnya menurut Kustandi dan Sutjipto (2011) media pembelajaran adalah alat yang dapat membantu proses belajar mengajar dan berfungsi untuk memperjelas makna pesan yang disampaikan, sehingga dapat mencapai tujuan pembelajaran yang lebih baik dan sempurna. Gagne dan Briggs (dalam Kustandi 2011) secara implisit mengatakan bahwa media pembelajaran meliputi alat yang secara fisik digunakan untuk menyampaikan isi materi pembelajaran, yang terdiri dari antara lain buku, tape recorder, kaset, video camera, video recorder,film, slide (gambar bingkai), foto, gambar, grafik, televisi, dan komputer.

\section{METODE PENELITIAN}

Penelitian ini merupakan penelitian tindakan bimbingan konseling yang terdiri dari dua siklus. Masing-masing siklus terdiri dari tahap: persiapan, perencanaan, pelaksanaan, observasi, dan refleksi. Penelitian ini dilaksanakan di SMP Negeri 5 Sibolga tahun pelajaran 2015/2016. Populasi dalam penelitian ini adalah seluruh siswa kelas VIII SMP Negeri 5 Sibolga.
Pengambilan sampel dilakukan dengan cara cluster random class dimana setiap kelas (acak kelas) memiliki kesempatan yang sama untuk menjadi sampel dalam penelitian. Sampel yang diambil adalah satu kelas yaitu kelas VIII-6 yang akan dibimbing melalui konseling eklektik dengan menggunakan media superhero.

Teknik pengumpulan data dilakukan dengan menggunakan angket berupa instrumen tes minat belajar.

\section{HASIL DAN PEMBAHASAN Hasil Analisis Pra Siklus}

Peneliti menyebarkan angket di kelas VIII-6 dan mendapatkan 4 siswa dengan kategori rendah yang kemudian akan melakukan konseling individu dengan media superhero. Hasil analisis minat belajar berdasarkan tes yang dilakukan yaitu :

Tabel 1. Minat Belajar Siswa Pada Tahap PraSiklus

\begin{tabular}{|c|c|c|c|}
\hline No & $\begin{array}{c}\text { Nama } \\
\text { Siswa }\end{array}$ & Skor & Kategori \\
\hline 1 & AZ & 60 & Rendah \\
\hline 2 & HOS & 62 & Rendah \\
\hline 3 & SAM & 64 & Rendah \\
\hline 4 & TG & 65 & Rendah \\
\hline & Jumlah & 251 & \\
\hline Rata-Rata & 62,75 & \\
\hline Nilai Tertinggi & 65 & \\
\hline Nilai Terendah & 60 & \\
\hline
\end{tabular}

Berdasarkan tabel di atas, siswa AZ memiliki skor 60 dengan kategori minat belajar rendah, siswa HOS memiliki skor 62 
dengan kategori minat belajar rendah, siswa SAM memiliki skor 64 dengan kategori minat belajar rendah, siswa TG memiliki skor 65 dengan kategori minat belajar rendah. Adapun skor rata-rata siswa 62,75 dengan skor tertinggi 65 dan skor terendah 60 . Dengan demikian, dapat disimpulkan bahwa sebelum diberikan layanan konseling eklektik dengan menggunakan media superhero, sampel yang berjumlah 4 orang memiliki tingkat minat belajarnya dengan kategori rendah.

\section{Hasil Analisis Sklus I}

Adapun gambaran hasil siklus I berdasarkan tabulasi angket dapat dilihat pada tabel 2 sebagai berikut :

Tabel 2. Minat Belajar Siswa Pada Tahap Siklus I

\begin{tabular}{|c|c|c|c|}
\hline No & $\begin{array}{c}\text { Nama } \\
\text { Siswa }\end{array}$ & Skor & Kategori \\
\hline 1 & AZ & 70 & Rendah \\
\hline 2 & HOS & 77 & Sedang \\
\hline 3 & SAM & 85 & Tinggi \\
\hline 4 & TG & 71 & Rendah \\
\hline \multicolumn{2}{|c|}{ Jumlah } & 251 & \\
\hline Rata-Rata & 62,75 & \\
\hline Nilai Tertinggi & 65 & \\
\hline Nilai Terendah & 60 & \\
\hline
\end{tabular}

Berdasarkan tabel di atas, siswa AZ memiliki skor 70 dengan kategori minat belajar rendah, siswa HOS memiliki skor 77 dengan kategori minat belajar sedang, siswa SAM memiliki skor 85 dengan kategori minat belajar tinggi, siswa TG memiliki skor
71 dengan kategori minat belajar rendah. Adapun skor rata-rata siswa 75,75 dengan skor tertinggi 85 dan skor terendah 70 .

Maka dari hasil siklus I sudah terjadi peningkatan minat belajar siswa yaitu sebanyak 50\%. Namun belum mencapai target yang diharapkan yakni $75 \%$.

\section{Hasil Analisis Siklus II}

Berikut adalah peningkatan minat belajar siswa sesuadah diberikan layanan sampai akhir siklus II.

Tabel 3. Minat Belajar Siswa Pada Siklus II

\begin{tabular}{|c|c|c|c|}
\hline No & $\begin{array}{c}\text { Nama } \\
\text { Siswa }\end{array}$ & Skor & Kategori \\
\hline 1 & AZ & 90 & Tinggi \\
\hline 2 & HOS & 92 & Tinggi \\
\hline 3 & SAM & 91 & Tinggi \\
\hline 4 & TG & 90 & Tinggi \\
\hline \multicolumn{2}{r|}{ Jumlah } & 363 & \\
\hline Rata-Rata & 90,75 & \\
\hline Nilai Tertinggi & 92 & \\
\hline Nilai Terendah & 90 & \\
\hline
\end{tabular}

Berdasarkan tabel di atas, siswa AZ memiliki skor 90 dengan kategori minat belajar tinggi, siswa HOS memiliki skor 92 dengan kategori minat belajar tinggi, siswa SAM memiliki skor 91 dengan kategori minat belajar tinggi, siswa TG meemiliki skor 90 dengan kategori minat belajar tinggi. Adapun skor rata-rata siswa 90,75 dengan skor tertinggi 92 dan skor terendah 90.

Maka dari hasil siklus II sudah terjadi peningkatan minat belajar siswa sesuai target yang diharapkan. 
Maka analisis datanya adalah sebagai berikut:

$$
\mathrm{P}=\frac{f}{n} x 100 \%=\frac{4}{4} x 100 \%=100 \%
$$

Hasil Analisis Penelitian Pra Siklus, Siklus

\section{I dan Siklus II}

Berikut adalah tabel peningkatan minat belajar siswa sesudah diberikan layanan sampai akhir siklus II.

Tabel 4. Minat Belajar Siswa Pada Tiap Siklus

\begin{tabular}{|c|c|c|c|c|c|}
\hline \multirow{2}{*}{$\begin{array}{c}\text { Nama } \\
\text { Siswa }\end{array}$} & $\begin{array}{c}\text { Pra } \\
\text { Siklus }\end{array}$ & $\begin{array}{c}\text { Siklus } \\
\text { I }\end{array}$ & $\begin{array}{c}\text { Siklus } \\
\text { II }\end{array}$ & \multicolumn{2}{|c|}{$\begin{array}{c}\text { Terjadi } \\
\text { Perubahan }\end{array}$} \\
\cline { 2 - 6 } & Skor & Skor & Skor & Skor & $\%$ \\
\hline AZ & 60 & 70 & 90 & 30 & 50 \\
\hline HOS & 62 & 77 & 92 & 30 & 48,39 \\
\hline SAM & 64 & 85 & 91 & 27 & $\begin{array}{c}42,18 \\
8\end{array}$ \\
\hline TG & 65 & 71 & 90 & 25 & 36,92 \\
\hline Jumlah & 251 & 251 & 363 & 112 & $\begin{array}{c}117,4 \\
98\end{array}$ \\
\hline Rata-Rata & 62,75 & 62,75 & 90,75 & 28 & 44,37 \\
\hline $\begin{array}{c}\text { Nilai } \\
\text { Tertinggi }\end{array}$ & 65 & 65 & 92 & 30 & \\
\hline $\begin{array}{c}\text { Nilai } \\
\text { Terendah }\end{array}$ & 60 & 60 & 90 & 25 & \\
\hline
\end{tabular}

Dari hasil skor angket yang diperoleh oleh masing-masing siswa dari pra siklus ke siklus I hingga siklus II dapat disimpulkan minat belajar siswa tersebut meningkat. Adapun hasil dari prasiklus, siklus I dan siklus II dapat diuraikan sebagai berikut :

1. AZ memiliki nilai minat belajar diri sebesar 60 pada pra siklus, pada siklus I memiliki nilai sebesar 70 dan di siklus II memiliki nilai 90. Dengan demikian AZ memiliki peningkatan minat belajar sebesar 30, maka dapat dikatakan bahwa
AZ mengalami peningkatan minat belajar sebesar $50 \%$.

2. HOS memiliki nilai minat belajar diri sebesar 62 pada pra siklus, pada siklus I memiliki nilai sebesar 77 dan di siklus II memiliki nilai 92. Dengan demikian HOS memiliki peningkatan minat belajar sebesar 30, maka dapat dikatakan bahwa HOS mengalami peningkatan minat belajar sebesar 48,39\%.

3. SAM memiliki nilai minat belajar diri sebesar 64 pada pra siklus, pada siklus I memiliki nilai sebesar 85 dan di siklus II memiliki nilai 91. Dengan demikian SAM memiliki peningkatan minat belajar sebesar 27, maka dapat dikatakan bahwa SAM mengalami peningkatan minat belajar sebesar $42,188 \%$.

4. TG memiliki nilai minat belajar diri sebesar 65 pada pra siklus, pada siklus I memiliki nilai sebesar 71 dan di siklus II memiliki nilai 90. Dengan demikian TG memiliki peningkatan minat belajar sebesar 25, maka dapat dikatakan bahwa TG mengalami peningkatan minat belajar sebesar $36,92 \%$.

Dengan demikian dapat disimpulkan bahwa nilai rata-rata siklus II lebih tinggi dari nilai rata-rata pra siklus yaitu 62,75 menjadi 90,75. Artinya ada peningkatan minat belajar 
siswa setelah diberikan layanan konseling eklektik dengan menggunakan media superhero dengan perubahan interval $28 \%$. Namun terdapat 1 siswa dengan peningkatan minat belajar yang rendah dibandingkan dengan teman-temannya yaitu sebesar 25 point. Diharapkan untuk guru BK lebih memperhatikan siswa tersebut dan memberikan bimbingan lanjutan agar siswa semakin meningkat minat belajarnya. Untuk lebih jelasnya dapat dilihat pada diagram batang berikut ini.

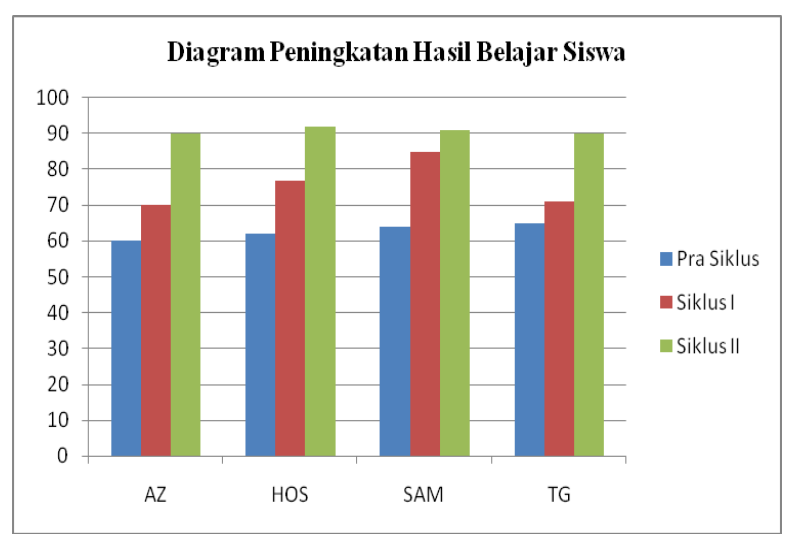

Gambar 1. Diagram Peningkatan Hasil Belajar Siswa Pada Tiap Siklus

Berdasarkan data penilaian proses konseling bahwa pada aspek prosedur konseling, pengentasan masalah, dan ketuntasan masalah mengalami peningkatan yang lebih baik. Namun peneliti disini masih tetap disarankan untuk latihan.

\section{Pembahasan}

Tindakan yang dilakukan melalui proses konseling mulai dari perencanaan hingga pelaksanaan maupun analisis verbatim terhadap konseling menunjukkan bahwa pelaksanaan konseling sesuai dengan RPLBK (Rencana Pelaksanaan Layanan Bimbingan dan Konseling) yang baik. Sehingga dapat dikatakan bahwa tindakan pada siklus I dan II memenuhi syarat dalam meningkatkan minat dalam belajar siswa. Meskipun di awal penelitian, siswa yang mengikuti kegiatan konseling masih merasa bingung dan ragu dengan kegiatan ini, tetapi mereka tetap mengikuti tahap demi tahap kegiatan dengan baik dan antusias.

Dengan adanya tahap-tahap konseling eklektik yang dikemukakan Adler yaitu tahap penghantaran, tahap penjajakan, tahap pengakhiran, tahap penilaian dan umpan balik, maka peneliti dapat melaksanakan semua tahapan dengan baik. Dengan adanya tahapan-tahapan tersebut maka konseling eklektik dengan menggunakan media superhero yang dilakukan berjalan terarah.

Sebelum dilaksanakan layanan konseling eklektik dengan media superhero, minat belajar siswa masih berada pada kategori kurang. Hal ini dibuktikan dari hasil angket yang telah dilakukan, dimana hasil tes menunjukkan bahwa siswa mengalami masalah dalam minat belajar. Dalam hal ini peneliti menggunakan layanan konseling 
individu dengan media superhero untuk meningkatkan minat belajar siswa.

Media superhero dalam penelitian ini dilaksanakan melalui konseling eklektik yang bertujuan untuk meningkatkan minat belajar siswa. Media superhero digunakan untuk menemukan kekuatan-kekuatan yang ada pada diri setiap siswa, yang mana superhero dijadikan sebagai figur, ataupun contoh tokoh. Yang tujuan sebenarnya melalui media superhero siswa bias mengatasi masalahnya dengan menemukan kekuatan-kekuatan dan pengalaman dirinya. Sebelum pelaksanaan konseling eklektik dengan media superhero ini, proses konselingnya terlebih dahulu melakukan visualisasi kreatif untuk membuat siswa focus terhadap kegiatan konseling, kegiatan ini sangat membantu peneliti. Selain membuat siswa fokus, siswa merasa lebih nyaman dan bias membangun keakraban antara peneliti dengan konseli.

Pelaksanaan konseling eklektik dengan media superhero dilaksanakan secara bersamaan, karena ini menggunakan konseling individu. Peneliti harus selalu bersedia kapanpun untuk melaksanakan kegiatan konseling. Saat melaksanakan penelitian ini peneliti juga mengalami beberapa kesulitan, yaitu : (1) waktu penelitian yang terbatas karena sudah mendekati kenaikan kelas, siswa harus fokus pada pelajarannya. Dan libur panjang sekitar satu bulan menyebabkan peneliti harus menunda kegiatan penelitian, (2) kurangnya pengetahuan siswa tentang konseling, menyebabkan peneliti harus membuat konseli mengerti setiap tahap konseling. Namun, peneliti berusaha untuk memberikan pemahaman terhadap konseli tentang tahapan kegiatan konseling. Selama proses penelitian, peneliti juga tetap latihan dan meminta perbaikan dari guru lainnya.

Sebelum dilaksanakan layanan konseling eklektik menggunakan media superhero, minat belajar siswa tergolong rendah dengan rata-rata 62,75 . Hal ini dibuktikan dari hasil angket dimana skor siswa menunjukkan minat belajar siswa rendah. Dalam hal ini peneliti menggunakan layanan konseling eklektik menggunakan media superhero untuk mengatasi masalah tersebut.

Hasil tindakan penelitian: (1) AZ mengalami peningkatan sebesar 50\%, (2) HOS mengalami peningkatan sebesar 48,39\%, (3) SAM mengalami peningkatan sebesar 42,188\%, (4) TG mengalami peningkatan sebesar 36,92\%. Dari data yang sudah ada terlihat bahwa peningkatan minat belajar terandah ada pada siswa TG untuk 
lebih giat lagi dalam belajarnya agar tidak tertinggal dengan teman lainnya. Adapun peningkatan minat belajar siswa tiap siklus dapat dilihat pada tabel 5 berikut.

Tabel 5. Peningkatan Hasil Minat Belajar Siswa Pra Siklus, Siklus I, dan Siklus II

\begin{tabular}{|c|c|c|c|}
\hline \multirow{2}{*}{ No } & \multirow{2}{*}{$\begin{array}{c}\text { Nama } \\
\text { Siswa }\end{array}$} & \multicolumn{2}{|c|}{$\begin{array}{c}\text { Peningkatan Minat } \\
\text { Belajar }\end{array}$} \\
\cline { 3 - 4 } & & Skor & Persentase (\%) \\
\hline 1 & AZ & 30 & 50 \\
\hline 2 & HOS & 30 & 48,39 \\
\hline 3 & SAM & 27 & 42,188 \\
\hline 4 & TG & 25 & 36,92 \\
\hline \multicolumn{2}{|c|}{ Rata-Rata } & 28 & 44,37 \\
\hline \multicolumn{2}{|c|}{ Nilai Tertinggi } & 30 & \\
\hline \multicolumn{2}{|c|}{ Nilai Terendah } & 25 & \\
\hline
\end{tabular}

Adapun tindakan yang dilakukan mulai dari perencanaan hingga tahap akhir dari siklus I sampai akhir siklus II berjalan sesuai dengan rencana pelaksanaan layanan konseling eklektik dengan media superhero, sehingga dapat dikatakan bahwa tindakan yang dilakukan pada siklus I dan siklus II dapat meningkatkan minat belajar siswa. Hal ini didukung oleh pepenelitian sebelumnya yang telah dilakukan oleh peneliti terdahulu bahwa penerapan bimbingan dan konseling dapat meningkatkan minat belajar siswa (Pramita, 2016).

Hipotesis dari penelitian ini adalah konseling eklektik dengan menggunakan media superhero dapat meningkatkan minat belajar siswa kelas VIII-6 di SMP Negeri 5 Sibolga. Hasil penelitian menunjukkan bahwa terjadi peningkatan minat belajar siswa yang menjadi subjek penelitian. Hal ini dibuktikan dari angket yang telah dilakukan dan laiseg. Berdasarkan ini dapat dinyatakan hipotesis penelitian ini "konseling eklektik dengan menggunakan media superhero dapat meningkatkan minat belajar siswa kelas VIII6 di SMP Negeri 5 Sibolga" dapat diterima. Artinya konseling eklektik dengan menggunakan media superhero dapat digunakan untuk meningkatkan minat belajar siswa.

Hasil penelitian ini mendukung pendapat Latipun (2011) bahwa tujuan konseling eklektik adalah membantu konseli mengembangkan integritasnya pada level tinggi, yang ditandai oleh adanya aktualisasi diri dan integritas yang memuaskan. Demikian juga dengan media superhero yaitu melalui pengalaman bermain fantasi dan bagi orang dewasa dapat menjadi sumber kekuatan bagi konseli untuk memahami diri, pertumbuhan dan penjernihan diri dengan baik melalui pemahaman terhadap peristiwa masa lalu, keadaan masa kini, dan keadaan masa depan yang diinginkan (Lawrence, 2007). Dengan media superhero ini dapat meningkatkan minat belajar siswa sebagaimana yang dikemukakan oleh Gie (2013) bahwa minat belajar adalah 
keterlibatan sepenuhnya seorang siswa dengan segenap kegiatan pikiran secara penuh perhatian untuk memperoleh pengetahuan dan mencapai pemahaman tentang pengetahuan ilmian yang dituntutnya di sekolah ini dibuktikan dengan menggunakan media superhero dapat meningkatkan minat belajar siswa. Minat mempunyai beberapa aspek diantaranya adalah perhatian, ketertarikan, keyakinan, dan tindakan. Perhatian, merupakan pemusatan dari siswa pada satu atau lebih objek yang menarik, dalam hal ini perhatian yang dimaksud adalah saat memperhatikan pelajaran yang disampaikan oleh guru. Ketertarikan, mempunyai pengertian bahwa awal tertariknya siswa terhadap suatu objek sehingga ada upaya yang dilakukan siswa untuk lebih mengenal objek tersebut. Keyakinan, yaitu suatu sikap yang ditunjukkan oleh siswa karena ia merasa cukup tahu tentang materi yang dijelaskan oleh guru. Setelah siswa merasa yakin dengan apa yang dipelajarinya, maka ia merasa tidak ragu dalam melakukannya dan memberikan dampak yang baik bagi siswa tersebut. Tindakan, adalah hal yang akan dilakukan siswa jika sudah memiliki perhatian, ketertarikan, keinginan, keyakinan dan keputusan. Setelah menentukan semuanya, siswa melakukan tindakan yaitu untuk melaksanakan dan memanfaatkan pelajaran yang ada di sekolah tanpa adanya paksanaan dari pihak lain melainkan dari dirinya sendiri.

Hal yang dapat disimpulkan adalah konseling eklektik dengan menggunakan media superhero dapat meningkatkan minat belajar siswa serta konseling eklektik menggunakan media superhero memiliki banyak manfaat bagi siswa, salah satunya dapat membantu siswa untuk semakin yakin dengan kemampuan diri sehingga dapat meningkatkan minat belajar siswa.

\section{PENUTUP}

\section{Simpulan}

Berdasarkan hasil pembahasan pada penelitian ini dapat disimpulkan bahwa adanya peningkatan minat belajar siswa melalui konseling eklektik dengan menggunakan media superhero pada siswa kelas VIII-6 SMP Negeri 5 Sibolga. Adapun hasil penelitian ini dapat dilihat dengan perolehan hasil rata-rata pra siklus sebesar 62,75 setelah dilakukan tindakan pada siklus diperoleh hasil siklus I sebesar 75,75 kemudian pada siklus II mengalami peningkatan menjadi 90,75. Hal ini menunjukkan adanya peningkatan minat belajar siswa sebesar $44,37 \%$.

\section{Saran}


Berdasarakan hasil penelitian yang telah dikemukakan sebelumnya dan dari kesimpulan, maka peneliti menyarankan, bagi sekolah diharapkan agar tetap mendukung kegiatan bimbingan dan konseling di sekolah untuk meningkatkan minat belajar siswa dalam belajar terkhusus melalui konseling elektik menggunakan media superhero. Bagi guru BK dapat menggunakan konseling elektik dengan menggunakan media superhero salah satu pemilihan tekhnik konseling untuk mengatasi masalah siswa terkhusus untuk meningkatkan minat belajar siswa di sekolah.

4. Bagi siswa yang masih memiliki nilai rendah, disarankan untuk mendapatkan tindakan khusus untuk menangani masalah minat belajar siswa.

\section{DAFTAR PUSTAKA}

Abror, Abd. Rachman. 1993. Psikologi Pendidikan. Yogyakarta : Tiara Wacana

Dalyono. 2009. Psikologi Pendidikan. Jakarta: Rineka Cipta

Djamarah, Syaiful Bahri. 2010. Strategi Belajar Mengajar. Jakarta : Rineka Cipta

Latipun, 2011. Memahami Dasar-dasar Konseling Dalam Teori dan Praktik. Jakarta : Kencana Prenada Media Group
Rubin, C, Lawrence. 2007. Using Superheroes In Counseling and Play Therapy. New York : Springer Publishing

Slameto. 2010. Belajar \& Faktor-Faktor Yang Mempengaruhi. Jakarta: PT Rineka Cipta

Tolbert, 2009. Dasar-dasar Bimbingan dan Konseling. Jakarta : Rineka Cipta

Winkel. 2009. Psikologi Pengajaran. Yogyakarta : Media Abadi 